\title{
Review: A French Treatise on Geology
}

Author(s): J. W. G.

Review by: J. W. G.

Source: The Geographical Journal, Vol. 31, No. 6 (Jun., 1908), p. 668

Published by: geographicalj

Stable URL: http://www.jstor.org/stable/1777635

Accessed: 27-06-2016 04:07 UTC

Your use of the JSTOR archive indicates your acceptance of the Terms \& Conditions of Use, available at

http://about.jstor.org/terms

JSTOR is a not-for-profit service that helps scholars, researchers, and students discover, use, and build upon a wide range of content in a trusted digital archive. We use information technology and tools to increase productivity and facilitate new forms of scholarship. For more information about JSTOR, please contact support@jstor.org.

The Royal Geographical Society (with the Institute of British Geographers), Wiley are collaborating with JSTOR to digitize, preserve and extend access to The Geographical Journal 


\section{MATHEMATICAL AND PHYSICAL GEOGRAPHY.}

\section{A French Treatise on Geologr.}

E. Haug, 'Traité de Géologie.' 2 vols. Vol. 1. "Les Phénomènes géologiques."

Pp. 385, 195 figs., 71 pl. Paris : Armand Colin. 1907. Price 12 fr. 50.

The relations of geography and geology are so increasingly intimate that the first volume of Prof. Haug's important 'Traité de Géologie' has an almost equal interest for geographers and geologists. The author is Professor of Geology in the University of Paris, and is well known for his valuable researches on the physical geography and geology of the French Alpine regions; and among the chief features of this book is its excellent statement of modern knowledge as to the structure of mountain chains, and the diagrammatic illustrations by which the author explains many of the terms and theories of Prof. Suess.

The author discusses the relations between geology and geography, and says that "while geography analyzes more or less exclusively the existing forms of the Earth's surface, geology primarily regards the succession of the phenomena that have brought about the existing forms, and it often too much neglects morphological considerations. Hence the two sciences tend to-day to blend intimately, the studies of physical geography taking more and more a geological character, and geology, under the vigorous impulse given by Suess, turning towards regional studies." He insists that one essential character of geology is that it deals, not with the world as it is at any one date, but with the succession of phenomena, and with that geological cycle which the geologist should always bear in mind.

The first volume of Prof. Haug's treatise being confined to "Geological Phenomena," it deals largely with the problems of Physical Geography in their geological aspects ; and even the most strictly geological chapters, such as the description of the material of the Earth's crust, may be read with interest and profit by geographers.

Among the chapters of special geographical interest are those summarizing biological geography. The evidence of the distribution of animals and plants is, in the author's opinion, conclusive against the belief in the permanence of ocean and continents. He holds that in Mesozoic times, the arrangement of land and water was fundamentally different from that of the present period, for there were then five great continents, one occupying the present basin of the North Atlantic; another most of the South Atlantic, connecting Africa and Brazil; a third covering most of the Indian ocean, and uniting Madagascar, India, and Australia; the fourth included China and Siberia; and the fifth and largest occupied most of the Pacific.

The author describes the Earth as composed of five zones, as, in addition to the ordinarily accepted divisions, he places a pyrosphere, constituted by a molten magma at a high temperature, between the lithosphere and the centrosphere. He accepts the hypothesis that the centre of the Earth is occupied by a metallic nucleus or barysphere, on the evidence afforded by the study of earthquakes; but his limitation of the term "barysphere" is an alteration in its meaning which will probably not meet with universal acceptance; and the very high density which the author accepts for the actual centre of the Earth is rendered improbable by Oldham's studies of the rate of transmission of earthquake shocks. The last chapter gives an account of the tetrahedral theory of the distribution of land and water, and helps to show the marked progress made in recent years by that once derided theory.

J. W. G. 